DOI: 10.20472/IAC.2018.001.020

\title{
PAWEENA SRIBUNRUENG
}

Suan Sunandha Rajabhat University, Thailand

KRIT CHAISANGDUEAN

Suan Sunandha Rajabhat University, Thailand

\section{WORKING ENVIRONMENT AND MOTIVATIONS EFFECTING THE EFFICIENCY IN EMPLOYEES' WORK PERFORMANCE: A CASE OF A TEXTILE AND CLOTHING INDUSTRIAL FACTORY IN THAILAND}

\begin{abstract}
:
The primary aim of this research was to study the influence of working environment and employees' motivation on the efficiency of their work performance. This research used a quantitative research approach. The research sample was 400 employees of a textile and clothing industrial factory in Thailand. The study was undertaken between June 1 and August 31, 2018. A questionnaire was used as a data collection tool. The collected data were then analyzed with descriptive statistics including frequency, percentage, and multiple linear regression. In terms of the sample's profile, most of them were female, between 20-30 years old, single, graduated below the undergraduate level, had working for more than 10 years, received around 15,001-20,000 bath per month. The research findings showed that these employees viewed that the overall working environment was significant for them. When considering at each aspect of the working environment, it was found that the each of the factors including the design of the working environment, structure of the office buildings, work structure, the efficient design of equipment and machines, safety and sanitation of working place, and process, was rated at a high level. As for the employees' motivation, it was found that the overall motivation, and each aspect of motivation including organizational policies and management, working condition, salary, job responsibilities, and progress in work were rated at a high level as well. The results of the hypothesis testing showed that working environment in the aspect of design of the working environment and safety and sanitation of the working place had an influence on the efficiency of the employees' work performance in terms of the quality of the outcome of work.
\end{abstract}

\section{Keywords:}

Working Environment, Motivations to Work, Efficiency in Work Performance

JEL Classification: Y80 


\section{Background and Significance of the Research}

Industries are economic sectors which are very significant for the country. They play an important role in the development of the country by establishing strengths and providing competitive advantages for the country. Labor is one part of the operation of the industries. At the present time, many countries including Thailand have been facing with a problem of labor shortage. They have to solve this problem by using labor from other countries. In Thailand, this situation is evidenced by the increasing number of foreign labor in many industries. The number of foreign labor has been doubled within less than 10 years between 2007 and 2015 (Ministry of Social Development and Human Security, 2016). These labor are from our neighboring countries. The reasons that these labor are popular are low wages used to hire them.

Although there are more foreign labor coming to work in many industries in Thailand, problems related to labor still represent major problems for many companies and factories. Apart from that labor shortage, a problem involving efficiency in working performance of the employees is also an obstacle for the effective operation of the organization.

The textile and clothing industry is one of the industries in Thailand that require a lot of skilled labor. This industry is likely to expand continuously which means that needs for more labor will significantly increase. With this reason, the researcher was interested to study the opinion of employees in the textile and clothing industry on the working environment and their motivation to work and a relationship between efficiency in working performance of the employees and working environment and their motivation to work.

\section{Research Objectives}

The primary aim of this research was to study the influence of working environment and employees' motivation on the efficiency of their work performance.

\section{Scope of the Research}

\section{Scope of population}

The population of this research were employees of a textile and clothing industrial factory in Thailand. 
Scope of time period of the study

The study was undertaken between June 1 and August 31, 2018.

Scope of variables

This study looked at two groups of variables as follows:

1) Independent variables included working environment of the office and the employees' motivations; and

2) Dependent variables included efficiency in the employees' work performance.

\section{Research Methodology}

As this study aimed to examine a relationship between two variables, a quantitative research approach was chosen.

Population and sample

The population of this study were employees of a textile and clothing industrial factory in Thailand. The sample size was calculated using Taro Yamane formula. The sample were selected via systematic sample. Fifty employees who worked between 10.00 a.m. and 4.00 p.m. were selected each day of eight days. As a result, 400 employees were selected as the sample of this study.

Data collection tool

Data were collected with the use of a questionnaire.

Data analysis

1) Data which were analyzed with descriptive statistics:

1.1) Data on the demographic background of the respondents were analyzed with frequency and percentage.

1.2) Data on the respondents' opinion on working environment and their motivation to work were analyzed by mean and standard deviation.

1.3) Data on the efficiency in work performance of the employee were analyzed by mean, standard deviation, maximum, minimum, frequency and percentage.

2) Data which were analyzed with inferential statistics to test the hypotheses:

A relationship between the independent variables including working environment and employees' motivation to work and dependent variable which was 
the efficiency in work performance was analyzed with regression analysis and multiple regression analysis with a .05 level of statistical significance.

\section{Results}

In terms of the sample's profile, most of them were female (56.31 percent), between 20-30 years old (37.88 percent), single (72.73 percent), graduated below the undergraduate level (78.79 percent), had working for more than 10 years (30.05 percent), received around 15,001-20,000 bath per month (47.47 percent).

As for the employees' satisfaction on working environment, the research results showed that in their point of views the overall working environment was significant for them $(\bar{X}=3.65)$. When considering at each aspect of the working environment, it was found that the structure of the office buildings being appropriately divided was the most important $(\bar{X}=3.86)$, followed by the efficient design of space, equipment and machines allowing for air flows $(\bar{X}=3.65)$ and lighting provided in the office being appropriate for eyes $(\bar{X}=3.43)$. The details were displayed in Table 1.

Table 1 Mean scores and standard deviation of the employees' opinion on working environment in terms of the design of working space.

\begin{tabular}{lccc}
\hline Aspects of working space design & Mean & S.D. & $\begin{array}{c}\text { Level of } \\
\text { Opinion }\end{array}$ \\
\hline $\begin{array}{l}\text { Lighting provided in the office being appropriate } \\
\text { for eyes }\end{array}$ & 3.43 & 0.73 & high \\
$\begin{array}{l}\text { The structure of the office buildings being } \\
\text { appropriately divided }\end{array}$ & 3.86 & 0.92 & high \\
$\begin{array}{l}\text { The efficient design of space, equipment and } \\
\text { machines allowing air flow }\end{array}$ & & & \\
\hline Average scores & 3.65 & 0.86 & moderate \\
\hline \hline
\end{tabular}


Table 2 Mean scores and standard deviation of the employees' opinion on working environment in terms of safety and sanitation in the office

\begin{tabular}{|c|c|c|c|}
\hline Aspects of safety and sanitation in the office & Mean & S.D. & $\begin{array}{l}\text { Level of } \\
\text { opinion }\end{array}$ \\
\hline $\begin{array}{l}\text { Having safe electricity system and personal protection } \\
\text { equipment }\end{array}$ & 3.72 & 0.84 & High \\
\hline \multicolumn{4}{|l|}{ Cleanliness of the office } \\
\hline \multirow{2}{*}{ Having sufficient fire extinguishers and fire brigades } & 0.46 & 0.15 & Mioderale \\
\hline & 3.64 & 0.82 & High \\
\hline Average scores & 3.59 & 0.80 & High \\
\hline
\end{tabular}

Based on the data shown in Table 2, the overall satisfaction of the employees on safety and sanitation in the office was high $(\bar{X}=3.59)$. When looking at each aspect of this working environment, it was found that in the opinion of the employees, having safe electricity system and personal protection equipment was the most important $(\bar{X}=$ $3.72)$, followed by having sufficient fire extinguishers and brigades $(\bar{X}=3.64)$, and cleanliness of the office $(\bar{X}=3.42)$.

Table 3 Mean scores and standard deviation of the employees' opinion on their motivations to work

\begin{tabular}{llll}
\hline Aspects of motivations & Means & S.D. & $\begin{array}{l}\text { Level of } \\
\text { Opinion }\end{array}$ \\
\hline Rate of salary being appropriate with job characteristics & 3.74 & 0.82 & High \\
Increase of salary being appropriate & 3.45 & 0.58 & moderate \\
& 3.78 & 0.89 & high \\
Payment of salary being efficient & 3.66 & 0.83 & High \\
\hline Average scores & & & \\
\hline
\end{tabular}

According to the data shown in Table 3, it was found that the employees had good high motivation to work in overall $(\bar{X}=3.72)$. When considering each aspect of motivation, the results showed that they paid a special attention on the payment of salary which should be efficient $(\bar{X}=3.78)$, meaning that they should receive salary on time. This was followed by the rate of salary what should be appropriate with their job characteristics $(\bar{X}=3.74)$, and the increase in the salary that must be appropriate $(\bar{X}=$ 3.45). 
The results of the hypothesis testing showed that working environment in the aspect of design of the working environment and safety and sanitation of the working place had an influence on the efficiency of the employees' work performance in terms of the quality of the outcome of work. This is consistent with the study of Duangta, Thubhiranrak, \& Khrueanamkham, (2017) which found that the employees of the local administrative organization thought that a motivation in a form of salary was the most important factor for them and affected their work performance the most.

\section{References}

Duangta, K., Thubhiranrak, T. \& Khrueanamkham, S., (2017). Factors influencing working efficiency of Finance Officers of the Sub-District Administrative Organizations, Udon Thani Province. SSRU Graduate studies journal, 10(1), 22-29.

Ministry of Public Health. (1993). Public Health statistics. Retrieved from http://bps.moph.go.th/new_bps/sites/default/files/statistic32-36.pdf

Ministry of Social Development and Human Security. (2016). Migrant Workers Statistics. Retrieved from https://www.m-society.go.th/article_attach/18712/20429.pdf

Prommayon, K. (2002). Alternative: The Efficiency of the Immigration Officers: A Case Study of the Immigration Officer in Sub-Division 1 and Sub-Division 2, Division. Unpublished independent study. Bangkok: Ramkhamhaeng University. 